\title{
Промяна на качеството на живот на пациенти c Presbyacusis
}

\author{
С. Върбанова ${ }^{1}$, Д. Попова ${ }^{1}$, Д. Попова \\ ${ }^{1}$ Медицински университет - София, Катедра по УНГ-болести, \\ Клиника по оториноларингология \\ ГУМБАЛ "Царица Йоанна" - София, \\ Клиника по метаболитни заболявания и диетика
}

\begin{abstract}
Introduction: Age-related hearing loss is commonly associated with degeneration of cochlear hair cells, mainly outer hair cells in the basal portion of the cochlea, and age related hearing impairment. Speech discrimination can be predicted relatively well on the basis of the elevation of the hearing threshold in disorders of the middle ear and the cochlea but the effect on the function of the nervous system may affect speech discrimination.

Material and methods: The patients analyzed are of ages from 70 to 85 years. Over the course of 4 months, they were treated with Omega-3 polyunsaturated acid fat, coenzyme Q-10, gama linoleic acid and vitamin $\mathrm{D}$ in certain proportions. The patients were tested before and after conception for: biochemical and nutritional status, mini-mental state examination and hearing tests, including subjective and objective measurements.

Results: The results showed that more of the old persons had quite a good estimate of their hearing capacity and tinnitus deprivation. Those used hearing aids showed improvements in comprehension and better language communication, resulting in greater self esteem.

Discussion: Treatment of disorders that are caused by expression of neural plasticity is in its infancy but the possibilities are there and future development most likely will provide adequate treatment of such disorders as tinnitus and speech discrimination.

Conclusion: We consider that the use of diet therapy as a treatment option for influencing the effect of presbyacusis is successful through changes in the cognitive and memory capabilities in patients over the age of 70 . The marked improvement of speech comprehension, especially with the assistance of a hearing aid, leads to a higher quality of life.
\end{abstract}

\section{Въведение}

Демографските анализи показват, че се увеличава броят на жителите на Земята над 65-годишна възраст и се прогнозира нарастването им над 1,5 билиона през 2010 година. Страните с най-голяма продължителност на живота, с изключение на Япония, са в Европа, между които е и България (1).

Presbyacusis най-често се свързва с дегенерации на външните клетки в базалната част на кохлеата и предизвиква възрастово обусловени слухови смущения (5). Сензоневралната слухова загуба при възрастни пациенти Presbyacusis в повечето случаи е съпроводена и от неприятен и безпокоящ шум Tinnitus $(2,3,4)$.

В процеса на стареене са възможните функционални промени в централните части на слуховия анализатор, в резултат на невралната пластичност. Нарастват доказателства, че функцията на централната част на слуховата нервна система може да се промени без отличими морфологични отклонения. Това е израз на neural plasticity, чрез която централната нервна система отреагира различно, в зависимост от начина на активация (9).

Израз на невралната пластичност при намаляването на високочестотните сигнали от кохлеата може да бъде и възприемането на шумове в ушите, без да има външен източник на звук. 


\section{Цел}

Целта на това проучване е да се проследи ефектът от прилагането на диетотерапията върху слуховата функция, шума в ушите и разбираемостта на говора при възрастни хора. Хранителният суплемент „Eskimo Brainsharp“ е включен като превантивен хранителен режим за проследяване повлияването на мозъчната дейност в напреднала възраст по отношение на подобряване на когнитивните функции, забавяне на процесите на стареене на мозька и възрастовите нарушения в паметта, концентрацията и способностите за запаметяване.

\section{Материал и методи}

Проследени са 27 пациенти (23 жени и 4 мъже) на възраст от 70 до 85 години, приемали 4 месеца омега 3 полиненаситени мастни киселини, коензим Q10, линоленова киселина и витамин D в определено съотношение. В началото и в края на проучването на пациентите бе проследен биохимичният и хранителен статус, регистрирани когнитивните възможности и отчетено функционалното състояние на слуховия анализатор.

\section{Резултати}

А. Според намалението на слуха при тонална прагова аудиометрия за говорните честоти:

1. при 14 възрастни (52\%) - средна слухова загуба до 30 децибела

2. при 12 от изследваните (44\%) - до 60 децибела

3. при 1 (4\%) от проследените възрастни - над 60 децибела

Б. Слухови апарати ползват 9 (30\%) от проследените.

В. Наличие на шум и състояние на слуховата функция:

1. социална - адекватен слух и шум в ушите се регистрира при 7 (26\%) от възрастните

2. намален слух и шум при 13 (48\%) от групата

Г. Честота на шума:

1. непостоянен при 9 (33\%) от проследената група

2. постоянен при 11 (40\%) възрастните

Д. Влиянието на шума върху качество на живот:

По отношение на влиянието на шума върху качество на живот преди приема на „Eskimo Brainsharp“ 5 споделят в интервютата си, че не са променили качеството си на живот, а 15 $(55 \%)$ от групата - че наличието на шумове в ушите оказва влияние върху ежедневието им по отношение на социални контакти, самочувствие и жизнената им активност.

След 4 месеца 19 (около 78\%) от възрастните съобщават за променено ежедневие, тъй като шумът не е така дразнещ и неприятен и не води до потиснато самочувствие и избягване на словесни контакти. Тази група от възрастни пациенти показа подобрена говорна разбираемост, особено отчетливо при използването на слухова протеза, и редуциране на влиянието на шума в ушите върху самочувствието, социалните контакти и качеството на живот.

Е. При проследяване разбираемост на говор (със и без слухова протеза) се отчете:

1. преди приема на „Eskimo Brainsharp“:

a) променена и затруднена словесна комуникация споделят 18 (66\%) от проследената група,

б) при $9(33 \%)$ липсват смущения.

2. след приема на хранителната добавка 20 (73\%) от тях съобщават за подобрена разбираемост на говора (със и без слухова протеза) особено при наличието на околен шум, което улеснява ежедневните им контакти и ги прави желани и приятни.

\section{Обсъждане}

Дискриминацията на говора може да се предскаже относително добре въз основа на елевацията на слуховия праг при смущенията в средното ухо и кохлеата, но увредата в централната част на анализатора на слуха може да повлияе говорната разбираемост.

Смущения, които нямат физиологична основа, понякога се отнасят към "функционални" с психологична или психиатрична етиология. Те могат да се причинят също и от биологични промени, каквито са и стареенето.

\section{Заключение}

Лечението на заболяванията, които се приемат за изява на neural plasticity, започва развитието си сега и може да повлияе и такива смущения като tinnitus и променената говорна разбираемост.

Ние считаме, че прилагането на диетотерапия и превантивни хранителни режими е възможно да промени качеството на живот при възрастните хора чрез повлияване на ефектите от процесите на стареене. 


\section{Литература:}

1. Haub C., 2006 World Population Date Sheet

2. Brechtelsbauer DA. Adult hearing loss. Prim Care 1990; 17: 249-66.

3. Jastreboff PJ. Tinnitus. In: Gates GA, ed. Current therapy in otolaryngology: head and neck surgery. 6th ed. St. Louis: Mosby, 1998: 90-5.

4. Griest SE, Bishop PM. Tinnitus as an early indicator of permanent hearing loss. AAOHN J 1998; 46: 325-9.

5. Möller AR Hearing : anatomy, physiology and disorders of the auditory system Sec. Ed., Elsevier, 2006.

6. Hendrickx JJ and all. Familial aggregation of tinnitus: a European multicentre study. B-ENT; 2007; 3 Suppl 7: 51-60.
7. Weinstein BE, Ventry IM. Audiometric correlates of the Hearing Handicap Inventory for the elderly J Speech Hear Disord. 1983 Nov; 48(4): 379-84.

8. Betlejewski S. Age connected hearing disorders (presbyacusis) as a social problem; Otolaryngol Pol.; 2006; 60(6): 883-6.

9. Möller AR. The role of neural plasticity in tinnitus. Prog Brain Res. 2007; 166: 37-45. 